\title{
The study of the language consciousness of russian and foreign military specialists by the method of associative experiment
}

\author{
M. N. Krotova ${ }^{1}$, A. P. Ushakova ${ }^{1}$
}

${ }^{1}$ Yaroslavl Higher Military School of Air Defense, 28 Moskovsky Prospekt, Yaroslavl 150001, Russian Federation

DOI: $10.18255 / 1996-5648-2021-2-276-289$

Research article

Full text in Russian

The article presents the results of a psycholinguistic study of the language consciousness of military specialists studying at the Yaroslavl Higher Military School of Air Defense. The study involved 100 people. These are representatives of the near and far abroad, as well as cadets from Russia. The main method used by the authors to compare the linguistic picture of the world, that is, linguistic and extralinguistic phenomena, the country of the language being studied and the country of the cadet's homeland, was an associative experiment. This method allowed us to identify markers for the consciousness of representatives of different linguistic worldviews (the core and the periphery in a particular field of consciousness), the value picture of the world within the framework of linguistic consciousness. Within the framework of this article, the authors presented an analysis of two words-stimuli-army and officer, which will allow us to determine the psychological features of language consciousness, taking into account the country of residence, educational and professional activities and professionalization of the individual. As a result of the experiment, the commonality of ideas and reactions to the basic concepts of militaryprofessional terminology is noted in all cadets, but the specific feature of the language consciousness formed by the native language for a long time (from 20 years or more), the culture and the structure of life of the cadet's homeland, which determines the unique and uncharacteristic reactions for the Russian language picture of the world, is highlighted.

Keywords: cadets; military university; foreign military specialists; language consciousness; associative experiment

\section{INFORMATION ABOUT AUTHORS}

\author{
Krotova, Maria N. | E-mail: gribok-masha@mail.ru \\ Cand. Sc. (Psychology), Senior lecturer \\ Ushakova, Alina P. | E-mail: ushakovalina@yandex.ru \\ Cand. Sc. (Philology), Associate Professor
}




\title{
Исследование языкового сознания российских и иностранных \\ военных специалистов методом ассоциативного эксперимента
}

\author{
М. Н. Кротова ${ }^{1}$, А. П. Ушакова ${ }^{1}$
}

${ }_{1}^{1}$ Ярославское высшее военное училище противовоздушной обороны, Московский пр., 28 , Ярославль, 150001, Российская Федерация

DOI: 10.18255/1996-5648-2021-2-276-289

УДК 159.9.072.432

Научная статья

Полный текст на русском языке

В статье представлены результаты психолингвистического исследования языкового сознания военных специалистов, обучающихся в Ярославском высшем военном училище противовоздушной обороны. В исследовании приняло участие 100 человек. Это представители ближнего и дальнего зарубежья, а также курсанты из России. Основной метод, используемый авторами для сравнения языковой картины мира, был ассоциативный эксперимент. Данный метод позволил выявить маркерные для сознания представителей разных языковых картин мира ориентиры (ядро и периферию в конкретном поле сознания), ценностную картину мира в рамках языкового сознания. Авторы представили анализ двух слов-стимулов - армия и офицер, которые позволяют определить психологические особенности языкового сознания с учетом страны проживания, учебно-профессиональной деятельности и профессионализации личности. В результате эксперимента отмечается общность представлений об основных понятиях военно-профессиональной терминологии у всех курсантов, но выделяется специфическая особенность языкового сознания, сфрориированного родным языком в течение длительного времени (от 20 лет и более), культурой и устройством жизни страны - родины курсанта, которая определяет уникальные и нехарактерные для русской языковой картины мира реакции.

Ключевыеслова: курсанты; военный вуз; иностранные военные специалисты; языковое сознание; ассоциативный эксперимент

\section{ИНФОРМАЦИЯ ОБ АВТОРАХ}

Кротова, Мария Николаевна

Ушакова, Алина Павловна
E-mail: gribok-masha@mail.ru

Кандидат психологических наук, старший преподаватель

E-mail: ushakovalina@yandex.ru

Кандидат фрллологических наук, доцент

(C) Кротова М. Н., Ушакова А. П., 2021

Статья открытого доступа под лицензией СС ВY (https://creativecommons.org/licenses/by/4.0/) 
Кротова М. Н., Ушакова А. П.

Современная методика обучения иностранному языку ставит основной целью не только выработку навыков практического владения языком, но и создание вторичной языковой личности, которая воспринимает чужой язык и чужую культуру как свои или, как минимум, не отторгает их и относится к ним с уважением. При обучении в военном вузе преподаватели должны как фрормировать у курсантов, прибывших из иностранных государств, чувства воинского долга, офицерской чести и достоинства, уважения к Вооружённым Силам и народам России, их истории, традициям и обычаям, так и учитывать особенности культуры страны - родины курсанта.

Отечественные исследования в области психологии, психолингвистики посвящены изучению функционирования человека в языке, то есть изучению языковой личности. В этом направлении представлены работы таких известных психологов, как А. Н. Леонтьева, Б. Ф. Ломова, А. В. Карпова, П. Я. Гальперина, Г. В. Акопова, В. П. Зинченко, А. А. Леонтьев и др. [1-7]. Согласно Б. Ф. Ломову, специфика сознания состоит в том, что оно является отражением, формирующимся и развивающимся в процессе исторического развития человека. То есть индивидуальное сознание формируется и развивается в неразрывной связи с сознанием общественным как психологический механизм включения индивидуального бытия в жизнь общества и общественного бытия в жизнь индивида [2]. Так, в своей научной работе Г. В. Акопов отмечает следующее: сознание, как идеальное явление, индивидуально для каждого человека. Любой психический опыт имеет субъектный, субъективный, личностный характер. И любое описание воспринимаемого человеком предмета или события носит личный характер. Но вместе с тем некоторые сущности и события могут одинаково восприниматься разными людьми. Это значит, что в самой вещи есть нечто общее для всех людей, несмотря на то что каждый психический опыт индивидуален и субъективен. И когда некий опыт одного человека совпадает с тем, что проживает и переживает другой, то опыт становится интерсубъективным. При этом интерсубъективность не означает отсутствия субъективности [5]. Когнитивное и языковое сознание личности выделил в своих работах П. Я. Гальперин [8]. Языковое сознание традиционно понимается как совокупность образов сознания, формирующихся при помощи языковых средств - слов, свободных и устойчивых словосочетаний, предложений, текстов и ассоциативных полей.

Диагностировать различие языковой картины мира носителя языка и иностранного военного специалиста можно с помощью ассоциативного эксперимента, который позволяет провести сравнение языковой картины мира (языковых и экстралингвистических явлений) страны изучаемого языка и страны - родины курсанта.

Целью нашего исследования является выявление специфических особенностей языкового сознания российских и иностранных военных 
Исследование языкового сознания российских и иностранных военных специалистов...

специалистов методом ассоциативного эксперимента. Мы предполагаем, что общая парадигма моделей ассоциирования у них совпадает, но актуальность различных моделей ассоциирования в данных культурах будет различной.

Практическая значимость исследования направлена на оптимизацию процесса овладения языковой компетенцией иностранными военными специалистами, изучающими русский язык, с учетом особенностей этнической культуры, национального языкового сознания, социокультурного стереотипа.

Описание выборки исследования. В эмпирическом исследовании приняли участие преподаватели кафедры русского языка, российские (1-3 курсы) и иностранные курсанты (1-5 курсы) Ярославского высшего военного училища противовоздушной обороны в количестве 100 человек. Возраст испытуемых - 19-30 лет. На момент проведения исследования иностранные военные специалисты имели разный уровень владения русским языком. Среди испытуемых из числа российских курсантов имелись билингвы.

Основной метод исследования - ассоциативный эксперимент. Нами был выбран цепочечный, или цепной, ассоциативный эксперимент; форма эксперимента - письменная (анкетирование). Данный тип эксперимента позволяет проводить исследование одновременно в большой группе испытуемых, контролировать время выполнения эксперимента, получать большой объём информации (слов-реакций) для анализа. В проведенном нами исследовании испытуемому предлагалось реагировать на стимул несколькими ассоциациями.

Ассоциация - это понятие, существующее в психолингвистике; обозначает связь объекта реальной действительности со сорормированным образом в человеческом сознании. Чаще всего ассоциации бывают типичными, стереотипными и иногда - уникальными. Наиболее частотные ответы называются культурно-первичными, они значимы с точки зрения языковой картины мира, в некоторой степени ее характеризуют.

В основе ассоциативного эксперимента лежит положение о том, что представители одной национальности выдают схожие реакции на определенные стимулы, анализ которых позволяет выделять ядро и периферию в конкретном поле для исследования. Следовательно, представители разных национальностей (например, российские курсанты, офицеры и иностранные военные специалисты) выдают разные реакции на слова-стимулы, т. к. за словами стоят понятия, а в них заключается жизненный опыт людей. Реакции респондентов позволяют говорить о маркерных для сознания ориентирах, о ценностной картине мира в рамках языкового сознания.

Ассоциативный эксперимент является относительно простым способом получения фрактических языковых данных, иллюстрирующих 
Кротова М. Н., Ушакова А. П.

специфику представлений о мире в целом и отдельных явлений в нем. С точки зрения психолингвистики и проведения ассоциативного эксперимента интерес представляет процесс освоения иностранного языка и «состыковка» элементов разных языковых систем в сознании, психологии формирования речи на иностранном языке [9-10]; умение правильно управлять разным набором языковых инструментов, дифференцировать языковые средства и разводить структурное наполнение без допущения ошибок и неточностей.

Для проведения ассоциативного эксперимента (составления анкет, написания инструкций, проведения анкетирования) были отобраны слова стимулы. Общая тематика слов - военная служба. Особенности реакций на слова-стимулы зависят от национальной принадлежности курсанта и его возраста. В ходе проведения эксперимента считается возможным отдельно проанализировать особенности языкового сознания иностранных военных специалистов ближнего и дальнего зарубежья, Азии и Африки и др.

Отобранные слова входят в активный словарный состав русского языка и используются иностранными специалистами в сфрере учебно-профессионального и профессионального общения. Данная лексика не требует дополнительного перевода, не встречается в ошибочном использовании лексемы в определенном контексте на продвинутых этапах обучения. К тому же данные лексические единицы отражают специфику получаемой профессии, в связи с чем важным представляется узнать отношение иностранных специалистов к данной профессии, чтобы, получив результаты, контролировать учебный процесс и учитывать особенности национального языкового сознания сначала при обучении русскому языку как иностранному, а затем и другим дисциплинам. Кроме того, учет освоения иностранными специалистами профессиональных лексем позволит оптимизировать процесс воспитательной работы в вузе[11].

В исследовании приняли участие курсанты с разным уровнем владения русским языком. Так, для российских курсантов русский язык является родным, для большинства иностранных военных специалистов ближнего зарубежья русский язык является знакомым еще до поступления в ЯВВУ ПВО, в некоторых странах русский язык - один из официальных языков (Кыргызстан, Казахстан) или язык межнационального общения (Узбекистан, Таджикистан, Азербайджан), для иностранных военных специалистов дальнего зарубежья русский язык - второй, третий иностранный язык. На реакции представителей дальнего зарубежья максимально влияет родной зык, картина мира, структурированная с помощью средств родного языка.

В связи с этим время на выполнение задании анкет ранжировано для трёх категорий обучающихся. Для курсантов Российской Федерации время выполнения заданий анкет максимально уменьшено (15 минут), 
для курсантов ближнего зарубежья - средний показатель времени (20 минут), для курсантов дальнего зарубежья - максимальный (30 минут).

Во время первичной обработки результатов эксперимента был проведен «вертикальный» анализ ответов для выявления правильности понимания испытуемыми полученных инструкций, а также для исключения из обработки испорченных листов. Дальнейшему анализу подвергались протоколы без учета количества полученных в них отказов, так как этот параметр не являлся важным для нашего исследования.

При анализе анкет российских военнослужащих было проведено сравнение полученных слов-реакций с данными ассоциативных словарей. При обработке анкет иностранных военных специалистов было проведён сравнительный анализ материалов анкет российских и иностранных военных специалистов. Сравнение реакций российских и иностранных военных специалистов позволяет выявить смысловые доминанты в исследуемой профессиональной сфрере и определить проблемные поля для межкультурной коммуникации в профессиональной сфере.

Для того чтобы выяснить, какие знания в нашем сознании связаны со словами того или иного языка, в РАН были инициированы несколько проектов по составлению ассоциативных словарей: Словарь ассоциативных норм русского языка под редакцией А. А. Леонтьева, Русский ассоциативный словарь, Славянский ассоциативный словарь.

Представители военной профессиональной субкультуры характеризуются общностью языка, общностью материальной и духовной деятельности, нравов и обычаев [12, с. 52]. Язык военнослужащего любого государства включает две ключевых подсистемы, которые могут вызвать трудности у человека, не посвященного в данную профессиональную среду: терминологию (регламентируемую официальными документами) и сленг. Обе подсистемы изобилуют различного рода аббревиатурами, поскольку отличительной чертой языка военнослужащих является его лаконичность. Слова, избранные для составления, отражают специфику избранной курсантами специальности.

Объем статьи не позволяет рассмотреть все реакции курсантов на предложенные слова-стимулы, поэтому мы остановимся на таких словах, как офрицер и армия. Данный выбор слов обусловлен их положением в частотном словаре военно-профессиональной терминологии.

Результаты проведённого ассоциативного эксперимента представлены ниже. Представлены реакции курсантов на предъявленные слова-стимулы. Реакции распределены по степени частотности и представлены в виде таблиц. После каждой таблицы даны сведения об отличиях ассоциативных полей, полученных в результате обработки материалов анкет носителей русского языка и носителей других языков - иностранных военных специалистов. Проведено сравнение обобщенной языковой карти- 
Кротова М. Н., Ушакова А. П.

ны мира, языковых и экстралингвистических явлений страны, в которой курсант проходит обучение языка и страны - родины курсанта.

Ассоциативное поле слова «офицер» у российских курсантов. При анкетировании российских курсантов популярными реакциями стали: улный (7\%), строгий (4\%), честнъй (3,9\%), силъный $(3,4 \%)$, ответственный (2,7\%), дисииплинированный (2,7\%), статный (2,4\%), мужественный (1,7 \%), образованнъй (1,2\%); существительными-реакциями: дисииплина (5\%), началъник (3, 4 \%), погонъ (2,6 \%), командир (2,4\%), уважение $(2,4 \%)$, защита (1,9\%), честь (1,2\%) (табл. 1$)$.

Таблица 1

Ассоциативное поле слова «офицер" у курсантов ближнего зарубежья

(числовые данные приведены в \%)

\begin{tabular}{|c|c|c|c|}
\hline \multirow{2}{*}{$\begin{array}{c}\text { Положение } \\
\text { в частотном } \\
\text { словаре }\end{array}$} & \multicolumn{3}{|c|}{ Родной язык } \\
\hline & Кыргызский & Таджикский & Узбекский \\
\hline Ядро & $\begin{array}{l}\text { честный } 10 \\
\text { звание } 6 \\
\text { форма } 6 \\
\text { армия } 4 \\
\text { достойный } 4 \\
\text { ответственность } 4 \\
\text { ответственный } 4 \\
\text { строгий } 4 \\
\text { честь } 4\end{array}$ & $\begin{array}{l}\text { честный } 8 \\
\text { умный } 8 \\
\text { защитник 5,4 } \\
\text { честь 5,4 }\end{array}$ & $\begin{array}{l}\text { сильный 13,3 } \\
\text { умный } 13,3 \\
\text { боевой 4,4 } \\
\text { старший 4,4 } \\
\text { строгий 4,4 } \\
\text { целеустремлённый 4,4 } \\
\text { честный 4,4 }\end{array}$ \\
\hline Периферия & $\begin{array}{l}\text { военнослужащий } \\
\text { гуманный } \\
\text { дисциплинированный } \\
\text { доблесть } \\
\text { добросовестный } \\
\text { жесткий } \\
\text { понятливый } \\
\text { порядочный } \\
\text { пример для подражания } \\
\text { сообразительность } \\
\text { справедливый } \\
\text { защитник } \\
\text { командир } \\
\text { красивый } \\
\text { лидер } \\
\text { многоффункциональный } \\
\text { мужественный } \\
\text { мужчины } \\
\text { отвага } \\
\text { стройность } \\
\text { умный } \\
\text { хитрый } \\
\text { человек слова } \\
\text { элита }\end{array}$ & $\begin{array}{l}\text { вежливость } \\
\text { военнослужащий } \\
\text { военный } \\
\text { грамотный } \\
\text { должен } \\
\text { достойный } \\
\text { здоровый } \\
\text { командный состав } \\
\text { мудрый } \\
\text { мужество } \\
\text { мужчина } \\
\text { надежда } \\
\text { образованность } \\
\text { патриот } \\
\text { полководец } \\
\text { преданность } \\
\text { пример } \\
\text { руководитель } \\
\text { серьёзный } \\
\text { сильный } \\
\text { уважение } \\
\text { учитель } \\
\text { человек в фрорме } \\
\text { честность }\end{array}$ & $\begin{array}{l}\text { бодрый } \\
\text { генерал } \\
\text { герой } \\
\text { грамотный } \\
\text { добровольный } \\
\text { добрый } \\
\text { задумчивый } \\
\text { звезда } \\
\text { командир } \\
\text { красивый } \\
\text { культурный } \\
\text { курсант } \\
\text { мы } \\
\text { он } \\
\text { отважный } \\
\text { ответственный } \\
\text { скромный } \\
\text { современный } \\
\text { суровый } \\
\text { уважение } \\
\text { форма } \\
\text { фуражка } \\
\text { я }\end{array}$ \\
\hline
\end{tabular}


Среди слов-реакций на стимул оббицер наблюдаются слова со значением субъекта: защитник, авторитет, генерал, капитан; деятельности: долг, забота, присяга, служба; атрибута: звёздъ, ,борла; качеств, характеристик: воля, верностъ, воспитанностъ; не наблюдается сем, называющих действие.

Расхождение слов-реакций и данных ассоциативных словарей [13] обусловлено влиянием профессиональной среды на мировоззрение и специфику языкового сознания курсантов.

Среди совпадающих реакций на стимул оgбицер следует отметить такие, как умный, честный, силъный, ответственный, честъ. Для реакций иностранных военных специалистов типичны конкретизации стимула и отношение офицера к военной организации, в связи с чем используются не только слова, называющие качества офицера, но и слова, подтверждающие его статус: бборма, звание, арлия. Указание на роль командира и уважение к нему имеется в реакции - стариий, что обусловлено традициями поведения в обществе страны - родины курсанта. Слова, называющие качества офрцера, находятся в основном на периферии, кроме тех, что указаны выше.

Профрессиональное языковое сознание определяет реакции в форме личных местоимений (он, мы, я), чего не наблюдается в ассоциативных словарях русского языка.

На периферии частотного словаря обеих групп военнослужащих находятся такие понятия, как гуманнъй, дисииплинированнъй, добросовестный, жесткий, понятливый, порядочный, справедливый, мужественный, военный, грамотный, достойный, здоровый, мудрый, серъёзный, силънъий и др. Данные реакции свидетельствуют об осознанном высоком статусе офицера в странах ближнего зарубежья и Российской Федерации.

При анализе ядра ассоциативного поля кусрантов из дальнего зарубежья отмечаются реакции, нехарактерные для проанализированных ранее ассоциативных полей, например: военное звание, капитан, добрый, серъёзный, подчинённый (табл. 2)

На периферии находятся слова, не названные в ассоциативном поле, составленном на основе анкет российских курсантов: вежливыц, жестокий, настоящий, неутомимый, правомочный, справедливый; команднъй пункт, команда, законъ, устав; курсовой (вместо - курсовой офицер), полковник, обицерский состав, началъник курса.

Рассмотрим ассоциативное поле слова «армия» у российских курсантов (табл. 3, 4).

При анкетировании российских курсантов популярными стали прилагательные-реакции: болъшая (2,7 \%), дисииплинированная (3,2\%), зелёная (2,2\%), могучая (2,2\%), многочисленная (1,7\%), сильная (4,9\%) устав- 
Кротова М. Н., Ушакова А. П.

ная (1,2 \%); существительные-реакции: коллектив (2,2 \%), оббицер (2,7 \%), порядок (5 \%), Россия (2,9\%), сила (2,9\%), солдатъ (2 \%), устав (2,1\%).

Среди слов-реакций на стимул армия наблюдаются слова со значением субъекта: военнослужащий, семъя, товарищ; деятельности: война, подготовка, работа; атрибута: щит, техника, кантик, автомат; качеств, характеристик: боевая, квадратнъй, красная, многонациональная, упорядоченная; не наблюдается сем, называющих действие.

Таблица 2

Ассоциативное поле слова «офицер" у курсантов дальнего зарубежья

(числовые данные приведены в \%)

\begin{tabular}{|c|c|c|c|c|c|}
\hline \multirow{2}{*}{$\begin{array}{l}\text { Положе- } \\
\text { ние в ча- } \\
\text { стотном } \\
\text { словаре }\end{array}$} & \multicolumn{5}{|c|}{ Родной язык } \\
\hline & Вьетнамский & Монгольский & $\begin{array}{c}\text { Португаль- } \\
\text { ский }\end{array}$ & Французский & Курунди \\
\hline Ядро & $\begin{array}{l}\text { военное зва- } \\
\text { ние 6,8 } \\
\text { добрый 6,8 } \\
\text { подчиненный } \\
6,8 \\
\text { смелый 6,8 } \\
\text { умный 6,8 }\end{array}$ & $\begin{array}{l}\text { добрый } 10 \\
\text { капитан 6,6 } \\
\text { сильный 6,6 } \\
\text { строгий 6,6 }\end{array}$ & \begin{tabular}{|l|} 
добрый 10 \\
ответствен- \\
ность 10 \\
решительный \\
10 \\
серьёзный 10
\end{tabular} & $\begin{array}{l}\text { ответствен- } \\
\text { ный 11,5 } \\
\text { умный 11,5 } \\
\text { дисциплини- } \\
\text { рованный 7,6 } \\
\text { порядочный } \\
7,6\end{array}$ & командир 20 \\
\hline Перифрерия & $\begin{array}{l}\text { авторитетный } \\
\text { дисциплини- } \\
\text { рованный } \\
\text { должность } \\
\text { классный чин } \\
\text { курсовой } \\
\text { майор } \\
\text { настоящий } \\
\text { приказ } \\
\text { решительный } \\
\text { служащий } \\
\text { служба } \\
\text { служить } \\
\text { справедливый } \\
\text { уважаемый } \\
\text { устав } \\
\text { характер }\end{array}$ & $\begin{array}{l}\text { военнослужа- } \\
\text { щий } \\
\text { вооружённый } \\
\text { жестокий } \\
\text { команда } \\
\text { командирский } \\
\text { майор } \\
\text { мужествен- } \\
\text { ный } \\
\text { начальник } \\
\text { начальник } \\
\text { курса } \\
\text { неутомимый } \\
\text { офицерский } \\
\text { офрицерский } \\
\text { состав } \\
\text { полковник } \\
\text { правомочный } \\
\text { смирно } \\
\text { умный } \\
\text { фрорма } \\
\text { храбрый }\end{array}$ & $\begin{array}{l}\text { генерал } \\
\text { капитан } \\
\text { командир } \\
\text { плохой } \\
\text { погоны } \\
\text { полковник } \\
\text { руководитель } \\
\text { смелость } \\
\text { смелый } \\
\text { уважение } \\
\text { уважаемый } \\
\text { хороший }\end{array}$ & $\begin{array}{l}\text { вежливый } \\
\text { выполнение } \\
\text { защитник } \\
\text { командир } \\
\text { майор } \\
\text { образование } \\
\text { опрятный } \\
\text { подразделе- } \\
\text { ние } \\
\text { полковник } \\
\text { приказ } \\
\text { серьезный } \\
\text { сильный } \\
\text { строгий } \\
\text { товарищ } \\
\text { честный } \\
\text { чистый }\end{array}$ & $\begin{array}{l}\text { законы } \\
\text { командный } \\
\text { пункт } \\
\text { ответствен- } \\
\text { ность } \\
\text { умный } \\
\text { устав } \\
\text { целесообраз- } \\
\text { ность }\end{array}$ \\
\hline
\end{tabular}


Ассоциативное поле слова «армия" у курсантов ближнего зарубежья (числовые данные приведены в \%)

\begin{tabular}{|c|c|c|c|}
\hline \multirow{2}{*}{$\begin{array}{c}\text { Положение } \\
\text { в частотном } \\
\text { словаре }\end{array}$} & \multicolumn{3}{|c|}{ Родной язык } \\
\hline & Кыргызский & Таджикский & Узбекский \\
\hline Ядро & $\begin{array}{l}\text { оружие 9,2 } \\
\text { сила 7,4 } \\
\text { большая 3,7 } \\
\text { война 3,7 } \\
\text { дисциплина 3,7 } \\
\text { защита 3,7 } \\
\text { организация 3,7 } \\
\text { сильный 3,7 } \\
\text { служба 3,7 } \\
\text { солдат 3,7 }\end{array}$ & $\begin{array}{l}\text { сила } 16 \\
\text { организация 13,9 } \\
\text { война 6,9 } \\
\text { мир 6,9 } \\
\text { вооруженные } \\
\text { силы 4,6 } \\
\text { защита 4,6 } \\
\text { самолеты 4,6 } \\
\text { солдаты 4,6 } \\
\text { страх 4,6 }\end{array}$ & $\begin{array}{l}\text { великий 5,8 } \\
\text { сильная 5,8 } \\
\text { военнослужащие 3,9 } \\
\text { оборона 3,9 } \\
\text { огромный 3,9 } \\
\text { оружие 3,9 } \\
\text { полигон 3,9 } \\
\text { служба 3,9 } \\
\text { трудный 3,9 } \\
\text { учение 3,9 }\end{array}$ \\
\hline Периферия & $\begin{array}{l}\text { БМП } \\
\text { военнослужащие } \\
\text { вооружённые силы } \\
\text { высококвалифициро- } \\
\text { ванный } \\
\text { государство } \\
\text { доблестный } \\
\text { дружба } \\
\text { единая } \\
\text { защитник } \\
\text { количество } \\
\text { корабли } \\
\text { красивый } \\
\text { маленькая } \\
\text { мир } \\
\text { многонациональная } \\
\text { могущество } \\
\text { мощный } \\
\text { наряды } \\
\text { общество } \\
\text { оперативный } \\
\text { организованный } \\
\text { перфекционисты } \\
\text { пистолет } \\
\text { ракета } \\
\text { сплочённая } \\
\text { страх } \\
\text { устав } \\
\text { школа }\end{array}$ & $\begin{array}{l}\text { боевые машины } \\
\text { вертолеты } \\
\text { войско } \\
\text { дружба } \\
\text { защитники } \\
\text { истребители } \\
\text { мужество } \\
\text { служить } \\
\text { танки } \\
\text { техника } \\
\text { фронт }\end{array}$ & $\begin{array}{l}\text { интересный } \\
\text { большой } \\
\text { взрослый } \\
\text { война } \\
\text { войско } \\
\text { воюет } \\
\text { гордость } \\
\text { готов } \\
\text { грозная } \\
\text { детство } \\
\text { дисциплина } \\
\text { жизнь } \\
\text { лучший } \\
\text { марширует } \\
\text { мир } \\
\text { объединение } \\
\text { офрицеры } \\
\text { охраняет } \\
\text { патрон } \\
\text { профеессиональная } \\
\text { прочный } \\
\text { советская } \\
\text { старик } \\
\text { строгий } \\
\text { сильный } \\
\text { танк } \\
\text { тренирует } \\
\text { узбекский } \\
\text { честность }\end{array}$ \\
\hline
\end{tabular}


Таблица 4

Ассоциативное поле слова «армия" у курсантов дальнего зарубежья (числовые данные приведены в \%)

\begin{tabular}{|c|c|c|c|c|c|}
\hline \multirow{2}{*}{$\begin{array}{c}\text { Положение } \\
\text { в частотном } \\
\text { словаре }\end{array}$} & \multicolumn{5}{|c|}{ Родной язык } \\
\hline & Вьетнамский & Монгольский & Португальский & $\begin{array}{c}\text { Француз- } \\
\text { ский }\end{array}$ & Курунди \\
\hline Ядро & $\begin{array}{l}\text { военнослу- } \\
\text { жащие 6,25 } \\
\text { народная } \\
6,25 \\
\text { сильная 6,25 }\end{array}$ & $\begin{array}{l}\text { мужчина 13,3 } \\
\text { сильная 13,3 } \\
\text { большая 5,4 } \\
\text { огромная 5,4 } \\
\text { оружие 5,4 }\end{array}$ & $\begin{array}{l}\text { Дисциплиниро- } \\
\text { ванный } 9 \\
\text { организован- } \\
\text { ная } 9 \\
\text { сильная } 9 \\
\text { служба } 9\end{array}$ & $\begin{array}{l}\text { вооружен- } \\
\text { ные силь } \\
10,3 \\
\text { оружие } \\
10,3 \\
\text { защитник } \\
6,8 \\
\text { силь 6,8 } \\
\text { сильная 6,8 }\end{array}$ & сильная 16 \\
\hline Периферия & $\begin{array}{l}\text { активная } \\
\text { вооруженный } \\
\text { военный } \\
\text { война } \\
\text { вооружен- } \\
\text { ные силы } \\
\text { Вьетнамская } \\
\text { народная } \\
\text { армия } \\
\text { дивизия } \\
\text { защищать } \\
\text { звание } \\
\text { корпус } \\
\text { курсанты } \\
\text { мертвый } \\
\text { мир } \\
\text { мировой } \\
\text { оружие } \\
\text { офриеер } \\
\text { парадный } \\
\text { прочная } \\
\text { слабая } \\
\text { советская } \\
\text { соединенная } \\
\text { устойчивая } \\
\text { человеческий }\end{array}$ & $\begin{array}{l}\text { американская } \\
\text { зарплата } \\
\text { качественная } \\
\text { командир } \\
\text { красная } \\
\text { место } \\
\text { мощная } \\
\text { награда } \\
\text { настоящий } \\
\text { одежда } \\
\text { офицер } \\
\text { приказ } \\
\text { руки } \\
\text { русская } \\
\text { сила } \\
\text { служба } \\
\text { солдат } \\
\text { строй } \\
\text { судьба } \\
\text { товарищ } \\
\text { требовать } \\
\text { фрорма } \\
\text { хорошая }\end{array}$ & $\begin{array}{l}\text { большая } \\
\text { военный } \\
\text { вооружённая } \\
\text { командир } \\
\text { курсант } \\
\text { маршал } \\
\text { однообразие } \\
\text { однообразная } \\
\text { оружие } \\
\text { патриотизм } \\
\text { порядок } \\
\text { способный } \\
\text { строгая } \\
\text { форма }\end{array}$ & $\begin{array}{l}\text { военные } \\
\text { воинские } \\
\text { части } \\
\text { защищать } \\
\text { знание } \\
\text { иерархия } \\
\text { необходи- } \\
\text { мый } \\
\text { обеспе- } \\
\text { ченная } \\
\text { оборона } \\
\text { конфрликт } \\
\text { самообла- } \\
\text { дание } \\
\text { сложный } \\
\text { человек }\end{array}$ & $\begin{array}{l}\text { вооружён- } \\
\text { ный } \\
\text { защищённый } \\
\text { оружие } \\
\text { слабая }\end{array}$ \\
\hline
\end{tabular}


В сознании российских и иностранных военнослужащих ближнего зарубежья стимул армия употребляется во всех свойственных ему значениях, названных в толковых словарях русского языка. Среди схожих реакции на стимул арлия прилагательные со значением характеристики: большая, силъная; существительное с качественным значением сила и существительное - субъект действия солдат.

Среди отличий - слова, обозначающие активную деятельность (война, защита, служба, оборона, учение), существительные с качественной семантикой (дисциплина, организация), существительные, называющие реалии армии (оружие, полигон, самолётъ). Данные реакции в ассоциативном поле стимула арлия у российских курсантов находятся на периферии. В реакциях российских военнослужащих отсутствуют глаголы, у военных специалистов с родным узбекским языком названы следующие: тренирует, охраняет, мариирует, что свидетельствует об активности роли субъекта (курсанта, офицера, солдата). В реакциях российских курсантов на активность субъекта указывают слова из периферии: работа, служба.

В ассоциативном поле иностранных военных специалистов наблюдаются слова-антонимы: война - мир, большая - маленъкая, мужество страх, красивыци - страшнъцй и др.

В ядре ассоциативного поля слова армия присутствуют слова, отсутствующие в ассоциативных полях, составленных на основе анкет российских курсантов: народная (родной язык - вьетнамский), мужчина, большая, огромная (родной язык - монгольский), организованная (родной язык - португальский), вооружённые силы, защитник (родной язык - португальский).

На периферии находятся ответы, не встречающиеся ранее. Это слова со значением субъекта: мариал, командир, курсант, человек; слова со значением действия: требоватъ, защищатъ; со значением характеристики: человеческий, советская, соединённая, прочная, параднъй, мировой, Въетналская народная арлия (родной язык - вьетнамская), качественная, красная, настоящая, американская, русская (родной язык - монгольский), вооружённая, однообразная, способный (родной язык - португальский), необходимъй, обеспеченная (родной язык - фрранцузский), защищённый, слабая (родной язык - курунди). Также на периферии слова, указывающие на организованность армии: иерархия, дивизия, корпус.

Сравнительно-сопоставительный анализ материала анкет, заполненных российскими и иностранными военными специалистами, показывает, что существует общность представлений и реакций на основные понятия военно-профессиональной терминологии. Однако в связи с особенностями языкового сознания, сорормированного родным языком 
Кротова М. Н., Ушакова А. П.

в течение длительного времени (от 20 лет и более), культуры и устройства жизни страны - родины курсанта присутствуют уникальные и нехарактерные для русской языковой картины мира реакции, что и представляет интерес для преподавателей русского языка иностранным военным специалистам на подготовительном и основном курсах.

Кроме того, профессиональная деятельность оказывает влияние на предметно-содержательные характеристики, состав и частотность ассоциативных реакций. Кроме общепризнанных в языковом сознании единиц, получены ассоциативные реакции, указывающие на профрессиональную деятельность военного.

Сравнительно-сопоставительный анализ материала, собранного с помощью ассоциативного эксперимента, позволил сделать вывод, что языковое сознание иностранных военных специалистов ближнего зарубежья наиболее близко языковому сознанию российских военных специалистов. Языковое сознание иностранных военных специалистов дальнего зарубежья также имеет общие черты с языковым сознанием носителей русского языка, что обусловлено влиянием общей профессиональной деятельности на сознание военных специалистов. Наблюдается явление наличия одинаковых реакций на слова-стимулы, но они (ассоциации) по-разному распределены в языковом поле (ядро и периферия).

При овладении избранной профессией иностранные военные специалисты усваивают систему и картину мира, присущую носителям русского языка. В условиях русской языковой среды существует необходимость формирования у обучающихся элементов «нового образа мира», соотносимого с образом мира носителей русского языка, владеющих той или иной профрессией. Формирование нового видения мира связано с формированием вторичной языковой личности.

\section{Ссылки}

1. Леонтьев А. Н. Деятельность. Сознание. Личность. М., 1975. 275 с.

2. Ломов Б. Ф. Сознание как идеальное отражение // Психология сознания / ост. и общ. ред. Л. В. Куликова. СПб.: Питер, 2001. С. 110-137.

3. Карпов А. В. Психология сознания. Метасистемный подход. М.: РАО, 2011. $1080 \mathrm{c}$.

4. Гальперин П. Я. К психологии фрормирования речи на иностранном языке // Психолингвистика и обучение иностранцев русскому языку. М.: Изд-во МГУ, 1972. C. $60-71$.

5. Акопов Г. В. Психология сознания: Вопросы методологии, теории и прикладных исследований. М.: Институт психологии РАН, 2010. 272 с. 
6. Зинченко В. П., Моргунов Е. Б. Человек развивающийся. М.: Тривола, 1994. 384 c.

7. Леонтьев А. А. Основы психолингвистики. М.: Смысл, 1999. 287 с.

8. Гальперин П. Я. Языковое сознание и некоторые вопросы взаимоотношения языка и мышления // Психология как объективная наука. М.: Институт практической психологии; Воронеж: Модек, 1998. С. 430-441.

9. Караулов Ю. Н. Показатели национального менталитета в ассоциативновербальной цепи // Языковое сознание и образ мира: сборник статей / отв. ред. Н. В.Уфримцева. М., 2000. С. 191-206.

10. Тарасов Е. Ф. Межкультурное общение - новая онтология анализа языкового сознания // Этнокультурная специфика языкового сознания / отв. ред. Н. В. Уфимцева. М.: ИЯ РАН, 1996. С. 7-22.

11. Антонова И. С. О соотношении понятий «языковое сознание» и «профессиональное языковое сознание» // Социосфрера. 2010. № 4. С. 52-57.

12. Бойко Б. Л. Основы теории социально-групповых диалектов: монография. М.: Воен. ун-т, 2008. 184 с.

13. Русский ассоциативный словарь. / Ю. Н. Караулов [и др.]. М.: АСТ, 2002. 781c. 